\title{
The architectural landscape of diverse ciliary functions
}

\author{
M Bettencourt-Dias*, S Chandra Jana, P Machado, J Rocha, S Mendonça, S Werner \\ From Cilia 2014 - Second International Conference \\ Paris, France. 18-21 November 2014
}

Cilia are microtubule-based membrane protrusions conserved across evolution involved in cell motility, fluid flow and sensing.

The diversity in functions is generally attributed to a core conserved microtubule-based structure, the axoneme, decorated by different structures, membrane and signaling systems. Here we study four classes of cilia that represent very diverse motility and sensory functions within a single organism, the fruit fly. We uncover that the base of the cilia, the basal body and transition zone, is much more diverse than previously thought, showing large variation in number, length, ultrastructure, and connection to other cellular structures. We further demonstrate that basal body diversity is imparted by differential regulation of evolutionarily conserved core components. The tissue specific regulation of core basal body and transition zone genes suggests mechanisms that generate tissue specific phenotypes in human ciliopathic syndromes.

Published: 13 July 2015

doi:10.1186/2046-2530-4-S1-013

Cite this article as: Bettencourt-Dias et al.: The architectural landscape of diverse ciliary functions. Cilia 2015 4(Suppl 1):013.

Instituto Gulbenkian de Ciencia, Oeiras, Portugal

Submit your next manuscript to BioMed Central and take full advantage of:

- Convenient online submission

- Thorough peer review

- No space constraints or color figure charges

- Immediate publication on acceptance

- Inclusion in PubMed, CAS, Scopus and Google Scholar

- Research which is freely available for redistribution
() Biomed Central

(c) 2015 Bettencourt-Dias et al. This is an Open Access article distributed under the terms of the Creative Commons Attribution License (http://creativecommons.org/licenses/by/4.0), which permits unrestricted use, distribution, and reproduction in any medium, provided the original work is properly cited. The Creative Commons Public Domain Dedication waiver (http://creativecommons.org/
publicdomain/zero/1.0/) applies to the data made available in this article, unless otherwise stated. 